\title{
National Traitors in Chicano Culture and Literature: Malinche and Chicano Homosexuals
}

\author{
Alma Rosa Alvarez \\ Southern Oregon University
}

This article examines the literary representation of a treatment of homosexuality in Mexican/Chicano culture. In this study, Alvarez argues that this cultural treatment is rooted in the gender paradigm central to Mexican/Chicano culture: the narrative of La Malinche.

In his novel The Miraculous Day of Amalia Gomez, John Rechy, a gay Chicano writer, tangentially illustrates how the issue of homosexuality fares within a Mexican/Chicano context: ${ }^{1}$ the protagonist, Amalia, condemns her son, Juan, for being gay, and her condemnation results in his expulsion from the family. Because notions of family in Mexican/ Chicano culture are inextricably tied to Catholicism, nationalism, and culture, Juan's exile extends beyond the family to include exile from Mexican/Chicano culture. What follows is a brief analysis of the connections between Catholicism, nationalism, and culture in traditional Mexican events and myths that have given rise to homophobic attitudes in Mexican/Chicano culture. Ultimately I argue that it is these types of traditional connections between Catholicism, nationalism, and culture in The Miraculous Day of Amalia Gomez that make the exile of the young gay Chicano, Juan, eminent.

Although many of Octavio Paz' statements in The Labyrinth of Solitude are controversial, particularly those dealing with Chicano culture and gender issues, his discussion of religion's place in Mexican society is generally accepted by the Chicano community. He asserts that the depth of Mexican religious feelings is located in "fiestas" as events of leisure containing both nationalist and religious symbolic importance. ${ }^{2}$ Paz claims that fiestas are events where the Mexican can open up and converse with "God, country, friends or relations," a phrase which highlights the most important elements of Mexican culture: religion, nationalism, and community. ${ }^{3}$ 
That notions of religion, nationalism, and community appear to be inextricably connected in a space where the Mexican is seemingly most at ease and ideologically vulnerable attests to their importance in Mexican culture. A clear example of the interconnectedness of religion and nationalism is the celebration of Mexican Independence Day. On the surface Mexican Independence Day appears primarily to be a state holiday; however, because the person responsible for the call to arms (a call for community) against Spain (nationalism) was a priest (Father Hidalgo) (religion), this national holiday is inescapably tinged with a religious communal strain.

Similarly, religious symbols such as Our Lady of Guadalupe are often found to contain a nationalist character. This is particularly evident in the unionization of farm workers under the direction of Cesar Chavez. Because the farm workers were primarily of Mexican origin, the union leadership in an attempt to organize the farm workers appropriated the religious image of Our Lady of Guadalupe as a unifying point. The Virgin's status as intercessor for Mexicans, her representation of Catholicism in a primarily Protestant nation (the United States), and her brown skin united the Mexican farm workers not only through religious appeal but also through what she represents in a geographical location away from home -- a shared lifestyle, race, culture, and religion. Thus in the U.S. Our Lady of Guadalupe goes beyond serving solely as a religious symbol; she takes on a nationalist character, while in turn the community of the farm workers union, through the use of Guadalupe's image, takes on a religious character. Notions of community, religion, and nationalism once again prove to be strongly interconnected elements in Mexican/Chicano culture.

Although the interconnection of community, religion, and nationalism can be important and empowering, there are situations in which these connections inhibit growth or discussion. In "Gay Liberation and Coming Out in Mexico," sociologist J. M. Carrier discusses the lack of sexual privacy among single Mexicans and links it to the Mexican familial system. Carrier explains that in Mexican society Mexican children tend to live with their families until marriage. The reason for this is that Mexican families are constructed on a communal level which promotes the existence of grandparents, parents, children and sometimes other extended family members in one household. ${ }^{4}$ As a consequence of communal living, which is provided by hierarchies of gender and age and cultural rules that are influenced by nationalist and religious ideologies, heterosexuality as well as homosexuality is monitored and repressed. The religious ideology forming the familial rules of the household is Catholicism under which any type of premarital sexuality is forbidden and illicit; thus Mexican families not only prohibit sons' and daughters' sexual conduct within the household but also prohibit the discussion of sexuality within the home. However, within Mexican culture women are bound to 
a double standard concerning sexuality; men are permitted to be sexually active outside of the home, while women are not. The cultural acceptance of this double standard is due, in part, to the Mexican's national collective psyche embedded in the myth of La Malinche.

La Malinche, a mythological figure from Conquest times, is the symbolic representation of the Indian women who were seduced and raped by the Spanish conquistadores. ${ }^{5}$ Perceived as cultural traitors to the Aztec nation for their "fleshly weakness," the blame levied on Indian women by the Aztec men was patriarchally informed because, in fact, more women were raped than seduced. Thus, the object of blame was not the mind or free will of the Indian woman but her body, vulnerable and literally or potentially open to foreign invasion. Malinche, through her own supposed openness as alleged translator and lover of Cortez, has been scapegoated and made the one figure responsible for the Spanish conquest. Because, according to popular myth, Malinche was at first embraced by the Spaniards and then discarded, La Malinche has been given the epithet "la chingada" or "the fucked one." This epithet overshadows the concept of Malinche's active betrayal by a passive one associated with an oral and vaginal openness considered inherent of her sex. ${ }^{7}$ The association of the female body with passivity and sexuality in conjunction with Catholicism have rigidified Mexican women's sexual roles, where under the guise of protection from falling into the Malinche trap and immorality, women are sexually repressed into chastity unless specified by morally sanctioned situations such as marriage.

On the other hand, because men's bodies are not genitally "open," men are not perceived as potential traitors and thus cannot be the "chingados." However, since Malinche is considered the symbolic mother of the Mexican race, men psychically feel part of the "chingado" legacy, a legacy of weakness. To not feel vulnerable, men disassociate themselves from the Indian mother/La Malinche by taking on the role opposite of "la chingada," "el chingon/the fucker," a man with an all-around aggressive sexual prowess. ${ }^{8}$ Through this role men become involved in sexual exploits where their partners are penetrated and shown to be, in comparison, weak, thus proving their strength and their own impenetra: bility or manhood. Since often the partner(s) are Mexican women, considered open and weak, a reenactment of the conquest of the Indian women occurs. In addition to reifying masculinity, the reenactment asserts the notions of nationhood: the potential offspring produced will be Mexican not only in literal terms but also in symbolic ones. Thus, the male macho in his escapades of illicit or marital sex subconsciously fulfills a nationalist desire as he participates in the creation of the Mexican race, just like his Spanish forefathers did.

The "homosexual" man's body, unlike the heterosexual man's, is perceived of as open. Therefore, the negative connotations of passivity, weakness, and betrayal that are associated with Mexican woman are 
associated with him. However, the homosexual man is further marginalized because unlike women his sexual acts are not procreative and do not reproduce the nation. Therefore, the homosexual is a national traitor. And because the Mexican concept of nation is one influenced by religion and culture, the homosexual is also a cultural and religious traitor.

In "Chicano Men: A Cartography of Homosexual Identity and Behavior," sociologist Tomas Almaguer argues that the oppression and devaluation of Mexicans/Chicanos in the U.S. heightens the cultural importance of the Mexican family; in a hostile environment the family becomes the primary economic, psychological, social, and cultural support system for survival in the U.S. ${ }^{9}$ The heightened familial relationship increases both the lack of sexual privacy and the importance of family attitudes which because of nationalist and religious influences are often anti-homosexual. Almaguer explains, however, that Mexicans/Chicanos are not necessarily more homophobic than members of other cultures, but that for Mexicans/Chicanos, homosexuality is constructed differently than for Anglo-Americans. Under Anglo-American sexual systems homosexuality is defined by the sexual object, while under a Mexican/ Chicano sexual system of socialization homosexuality is defined by sexual aim. ${ }^{10}$ What this means is that for Mexicans the receiving agent in anal intercourse (called by Mexicans pasivo/passive) is constructed as feminine and homosexual, while the active inserting agent (called activo/active) is masculine and heterosexual. The distinction between pasivo and activo demonstrates the workings of the chingon/chingada dichotomy. On the other hand, according to Anglo-American definitions, both of these roles are considered homosexual because they involve a same sex love object. Almaguer explains that the "gay" Chicano's lack of privacy in the family and his straddling of both the Mexican and AngloAmerican cultures and their sexual systems create conflicts which he must solve by "negotiating" his sexual identity between these two systems." Negotiation of sexual identity for the Chicano also means negotiation of cultural identity, so that negotiation involves many risks.

One of the negotiation risks for the activo male is that his family, socialized under the Mexican sexual system, may negate his sexual identity as a U.S. homosexual because for the family and Mexican culture the activo is not homosexual. Denial of the male's sexual identity occurs because accepting his homosexuality in American terms signifies the family's assimilation into American culture, and assimilation is perceived as counterproductive to the Mexican/Chicano family particularly if the family or its members have been subjected to discrimination. As a contradistinction the pasivo Chicano is not necessarily denied sexual identity; instead he runs the risk of being considered by his family/community a cultural traitor or malinchista ${ }^{12}$ for accepting what the family/ community believes is an Anglo-American behavior. ${ }^{13}$ What is striking in 
both the activo and pasivo situations is that in determining "true" homosexuality the family privileges ethnicity and culture over overt sexuality. Thus, the axiom in place in Mexican/Chicano culture is that to be a "true" Mexican/Chicano the subject cannot be homosexual. Because family is predicated on notions of nation, culture, and religion, a particular closed model of family and family unity gets reified with the repression of homo/ sexuality.

Examples of the conflict between Mexican/Chicano manhood and homosexuality can be found in literature as well as in sociological treatises. In Rechy's The Miraculous Day of Amalia Gomez, a conflict between nationalism (culture and religion) and sexuality arises. Throughout the novel the protagonist, Amalia, has difficulty dealing with her adolescent children's emerging sexualities. Instead of attempting to control their sexualities Amalia denies them, blocking communication between herself and her children, so that, in fact, Amalia feels left out of their lives. ${ }^{14}$ However, it may be not that Amalia's children have excluded her from their lives but rather that Amalia in her denial of their sexuality, a prominent element of adolescence, has excluded herself from them. This is evident in the opening section where Amalia is preoccupied with Juan's and Gloria's behaviors. Concemed about Juan she says, "Worries about Juan!--handsomer each day and each day more secretive ... . Was he in a gang?"15 Unequivocally, Amalia's primary concern with regards to Juan is his possible involvement in gangs. Amalia's fear is legitimatized by her geographic locale in a gang-ridden neighborhood and by her experience with her oldest son, a gang member who committed suicide in prison. However, the words "handsome" and "secretive" are sexual and aesthetic markers which reveal that Amalia subconsciously worries about Juan's sexuality.

Similarly Amalia avoids Gloria's sexuality; however her concern for Gloria's sexuality is more pronounced than her concern over Juan's because Gloria is a female. Amalia's concern is based not only on traditional Mexican views of female roles and sexuality but on her own sexual experience in adolescence which reinforced repressive sexual roles: Amalia as a teen is sexually abused by her father and then raped by her father's friend's son. In both events the violator's actions are not questioned. Instead, Amalia, like her pre-Columbian predecessor, Malinche, is blamed. And so Amalia as an adult feels cause for alarm in regard to Gloria and says, “And who wouldn't worry about Gloria? So very pretty and wearing more and more makeup, using words even men would blush to hear. ${ }^{n 6}$ As in the case with Juan, Amalia's conscious concem seems to be on a social level of propriety, seemingly divorced from sexuality: Gloria cusses. However, the fact that Gloria "us[es] words even men would blush to hear" suggests a latent manifestation of sexuality; after all, most cuss words have a sexual referent. This subtle suggestion is enforced by what precedes it: Amalia's obvious concem about Gloria's 
physical appearance. Amalia's focus on Gloria's "prettiness" heightened by Gloria's use of make'ip is not out of the ordinary given that Amalia's initiation into sexual relations of disempowerment have consistently started with the violator's remarks on Amalia's beauty. In actuality, then, Amalia's concentration on Gloria's "prettiness" is Amalia's own code word for sexuality.

Amalia's denial of her children's sexuality is based not only on Mexican/ Chicano roles but also on her attempt to create a cultural, theological model of compassion and understanding in terms of sexuality. Amalia is very much a product of the cultural system she has been reared in where malinchismo is an inherent possibility for women. As such she has been continuously blamed, first for the sexual abuse from her father and then her teenage rape at the hands of a family acquaintance whom she is forced to marry. The blame for her violated sexuality comes primarily from her family--from her father but most importantly from her mother, Teresa, who upon learning that her daughter has been raped refuses to discuss it since sexuality in an unmarried woman is not supposed to exist. Teresa's silence only serves to harbor feelings of guilt in Amalia, a guilt which Teresa then uses to incriminate her. The lack of comprehension from Teresa is symbolized by her devotion to "The Mother of Sorrows," an image of the Virgin Mary "somber . . . with a face of constant endured pain" whose long black robe hides her body and desexualizes her. ${ }^{17}$

As an adult Amalia adopts her favorite image of the Virgin Mary in the figure of "The Blessed Mother" in an attempt to avoid internalizing the blame for her violated sexuality. Unlike the Mother of Sorrows the Blessed Mother is robed in blue and has open outstretched arms, symbolizing her understanding and comprehension. For Amalia the Blessed Mother's understanding, however, comes from Amalia's attempt to purify herself through her evasion of blame. Whereas in this model Amalia eludes all blame and absolves herself through her prayers and conversations with the Blessed Mother, she accomplishes this through the denial of her body, which in fact is a denial of her sexuality. Therefore, even Amalia's compassionate and understanding model of theology is not comprehensive enough to include sexuality. What this translates to for her children is that comprehension is at the expense of their sexuality. In a sense, then, although Amalia has internalized the idea that sexuality, particularly hers, is "shameful and sinful," her model replicates the lack of communication that existed between herself and her mother, a lack which threatens the family unity necessary for Chicanos' survival in the U.S.

Nonetheless, in the narrative an opportunity for momentary family unity arises around notions of nationalism just as such opportunities arise for Mexican/Chicano families in the U.S. The catalyst for this unity is Mick, Gloria's current boyfriend, who is ashamed of being Mexican American. After Gloria accuses Mick of not being a "real Chicano guy" 
because he is afraid of Chicanos, Amalia launches a nationalist attack on Mick. ${ }^{18}$ She begins by deliberately calling Mick, Miguel, his actual name, and elicits the following response from him: "I told you l'm Mick and I don't speak Messican." ${ }^{\prime 19}$ Amalia's provocation proves to be successful in that both Juan and Gloria ally themselves with her in attacking Mick's assimilation. Amalia's family locates Mick's assimilation, however, in the Malinche myth of openness and betrayal. Thus Mick's assimilation is thought to affect not only his position vis a vis nationalism but also by extension his manhood and religious background. The collapse of these issues into assimilation becomes evident when Gloria calls Mick a "born-again Chicken," and her family concurs. ${ }^{20}$ Because assimilation is a form of openness to new cultures and because openness in Mexican/Chicano culture is associated with passivity, femininity, and betrayal (la Malinche), Mick, in being called a "Chicken," is denied his manhood. Mick's alleged passivity also leads Amalia's family to assume that Mick is a Protestant. It has been assumed that Mick, like Malinche, has been conquered but in this instance by Americanism, which for them automatically entails Protestantism. Mexican/Chicanos engagement in Protestantism is often perceived of as a form of malinchismo by other Mexican/Chicanos, particularly since in the U.S. Protestantism has often taken the form of cultural imperialism, so that even AngloEuropean Catholic churches in the U.S., in order to avoid Protestant antagonism, have changed their images and joined the racial attack on Mexican Catholics. It is Mick's perceived vulnerability and openness to new national identity, which for Amalia and her family entails a change in religion, that aligns Mick with Malinche. This association removes him from being identified as a Mexican/Chicano man.

The family unity and closeness with Juan and Gloria that Amalia revitalizes make her believe that in fact she possesses good mothering skills:

she cherished that she and her children were allied against the hateful young man .... Yes, she felt good, doubly so because her children had never been ashamed of being Mexicans; she taught them correctly, they were Mexican-Americans, like her. ${ }^{21}$

In turn her pride in having her children follow her good example on ethnic pride leads her to rationalize that she has a good family unit, and as such, it will defend her from oppression such as Mick's intemalized racism. At this point in the narrative the previous problems of communication with Juan and Gloria no longer matter to her. Her faith in a good family structured around good mothering for maintaining Mexican nationalism rooted in malinchismo leads her to think that those "cherished moments [of alliance] would make whatever would follow easier. ${ }^{\text {222 }}$ And, in fact, Amalia's belief in this type of family unity is reinforced when Juan, in a Chicano male stance, defends her, the family, and by extension 
Mexican nationalism by socking Mick in the face after Mick yells to Amalia, 'Where's all that pride bullshit got you? ... What are you? Just another fuckin' Mexican maid. ${ }^{\text {23 }}$

Ironically, it is nationalism rooted in Malinchismo which destroys family unity. Mick responds to Amalia and her family by manipulating the same Mexican rules on masculinity that called into question his own manhood; he introduces not only sexuality but homosexuality. He tells Amalia, "At least I wasn't busted for being a fag, like your son!"24 Mick succeeds in erasing the imposed category of malinchista, because whereas he symbolized ideological openness which is theoretically not permanent, Juan, in being labeled a "fag," represents bodily openness which is permanent and thus is always a symbol of betrayal to the nation, religion, and the family which is constructed through these. At this point Amalia focuses her energies on Juan and his sexuality with the following demand: "I want you to tell me now that you are not a maricon ... . . Tell me that now. ${ }^{25}$ By saying this Amalia has unwittingly destroyed the family unity she constructed.

Even in a situation where she is squarely confronted with sexuality, Amalia tries not to deal with it. Although she does not show the same type of intolerance as her mother did towards sexuality, Amalia's adherence to her theological model of compassion and understanding attempts to deny Juan's sexuality and by extension his subjectivity as a gay male. Amalia's demand, "Tell me now that you are not a maricon," ${ }^{26}$ is her attempt to purge Juan from all blame. Juan's negation would serve then to reconstruct the family as she had constructed it moments earlier around a sense of nationalism and a latent religiosity.

Juan's refusal to deny his sexuality forces Amalia to deal with sexuality. Seeing that her model of compassion has failed and having no other model with which to deal with sexuality other than her mother's, Amalia replays the scene after her rape: just as her rapist calls her a "puta" and her family silently agrees, Amalia calls Juan a puto, a derogatory term referring to the homosexual passive agent. Use of this epithet demonstrates that Amalia has made the assumption that Juan, labeled and self- identified as homosexual in American terms, is also homosexual in Mexican terms. In fact she has no knowledge of his private sexual preference. Amalia succeeds in reconstructing a malinche scene, demonstrating one of the difficulties the Chicano gay male experiences when operating within both the Mexican and Anglo-American sexual systems. Juan's admittance of his homosexuality in U.S. terms and thus acknowledgment of his privacy, shows his lack of desire to negotiate between both systems of socialization. This transgression marks him, in Amalia's mind, as an outsider to the family and by extension to Mexican/Chicano culture, especially since Amalia has constructed the notion of family around a nationalism that is exclusive of sexuality. Her statement, "You are not a joto, no son of mine could be, ${ }^{27}$ reinforces Juan's expulsion 
from the family and from Chicano cultural constructions of manhood in spite of the fact that earlier he had defended the family. Juan has become a cultural outlaw.

In The Miraculous Day of Amalia Gomez, Rechy has illustrated a movement, the movement of the gay Chicano from within the Mexican/ Chicano family and culture to outside of that family and culture. In doing this he points to the gay Chicano's precarious position within the Mexican/Chicano family and culture. Most significantly, however, Rechy subtly demonstrates the underpinnings of this movement, a particular combination of religion, nationalism, and culture. By doing this Rechy forces the reader to question and explore the traditional locus of these three elements that have also played a significant role in shaping the Chicano Movement.

\section{NOTES}

'Although I recognize that Mexican culture and Chicano culture are two distinct cultures, in this paper I conflate the two because in terms of the subject matter--attitudes on homosexuality--both cultures share the same points of origin.

'Octavio Paz, The Labyrinth of Solitude and Other Writings (New York: Gove Weidenfeld, 1985), 25.

3Paz, 49.

"Joseph M. Carrier "Gay Liberation and Coming Out in Mexico," Gay and Lesbian Youth ed. Gilbert Herdt (New York: Harrington Park Press, 1989), 226-248.

${ }^{5} \mathrm{Paz}, 86$.

${ }^{6} \mathrm{Paz}, 86$.

'Malinche, aside from being Cortez' lover, is also thought to have divulged through translations what the weak points of the Aztecs were. Because of this Malinche is said to have been orally open.

${ }^{8 P a z}, 82$.

9Tomas Almaguer "Chicano Men: A Cartography of Homosexual Identity and Behavior," The Lesbian and Gay Reader (New York: Routledge, 1993), 255-73.

${ }^{10} \mathrm{Almaguer,} 257$. 
Ethnic Studies Review Vol. 20

"Almaguer, 255.

${ }^{12} \mathrm{Paz}, 86$. Paz describes malinchistas as "those who want Mexico to open itself to the outside world."

${ }^{13}$ Almaguer, 262.

${ }^{14} \mathrm{~J}$ ohn Rechy, The Miraculous Day of Amalia Gomez (New York: Arcade Publishing, 1991), 11.

${ }^{15}$ Rechy, 8.

${ }^{16}$ Rechy, 8.

${ }^{17}$ Rechy, 13.

${ }^{18}$ Rechy, 180.

${ }^{19}$ Rechy, 178.

${ }^{20}$ Rechy, 180.

${ }^{21}$ Rechy, 179, my emphasis added.

${ }^{22}$ Rechy, 179.

${ }^{23}$ Rechy, 181.

${ }^{24}$ Rechy, 181.

${ }^{25}$ Rechy, 182.

${ }^{26}$ Rechy, 182.

${ }^{27}$ Rechy, 183.

Alma Rosa Alvarez is an Assistant Professor in the Department of English at Southern Oregon University. Currently, she is working on the representations of Catholicism in Chicano literature. 